\title{
Ocratoxina A em café: controle e metodologia analítica com ênfase a inovação no contexto de segurança alimentar
}

\section{Ochratoxin A in coffee: control and analitical methodology with emphasis in food safety}

\author{
Simone Fujii1*; Elisabete Yurie Sataque $\mathrm{Ono}^{2}$; Elisa YokoHirooka ${ }^{3}$
}

\section{Resumo}

A cafeicultura brasileira se destaca no mercado interno e comércio exterior, com ênfase a contaminação fúngica e ocratoxina A (OTA). A cafeína destaca-se entre os componentes naturais de defesa capazes de inibir produção de micotoxinas em café, inclusive a ocratoxina A (OTA), que vem constituindo num dos tópicos primordiais no controle de qualidade no mundo globalizado. Considerando que a garantia de matéria prima através de técnicas moleculares apresenta sérias barreiras na segurança alimentar, o constante monitoramento de toxinas ainda constitui opção para solução imediata do problema. As desvantagens inerentes à metodologia analítica química estimularam o emprego de imunoensaio "enzyme linked immunosorbent assay" (ELISA) e colunas de imunoafinidade como alternativas promissoras na detecção de OTA em alimentos. Visando garantir a qualidade de café sob o tópico de segurança alimentar, a revisão discerne sobre cafeína como componente de defesa natural de planta, aliado a métodos simples de elevada sensibilidade, indispensáveis no diagnóstico rápido de ocratoxinas a nível de campo.

Palavras-Chave: Ocratoxina, café, cafeína, segurança alimentar.

\begin{abstract}
The Brazilian coffee is one of the most important product in the national and international trade, with emphasis on fungal and ochratoxin A (OTA) contamination. The caffeine is spotted among natural mechanism of defense capable to inhibit mycotoxins production, including OTA which is continuously discussed in the globalized world. Concerning that transgenic plants produced by molecular techniques are motive of serious barriers in the food safety, the classic toxin monitoring still continues option for safety problem solution. The disadvantages concerning chemical methods stimulated development of enzyme linked immunosorbent assay (ELISA), and imunoaffinity as promising alternative for the detection of OTA. With intention to guarantee the quality of coffee, the revision discerns about caffeine as a component of natural defense of plant, in parallel to highly sensitive simple tool, which can be indispensable for ochratoxin diagnosis at field level.
\end{abstract}

Key Words: Ochratoxin, coffee, caffeine, food safety.

\footnotetext{
1 Farmacêutica Bioquímica formada pela Universidade Estadual de Maringá, Mestranda do Curso de Ciência de Alimentos do Departamento de Tecnologia de Alimentos e Medicamentos da Universidade Estadual de Londrina. Email: simonefujii@uel.br.

2 Docente do Departamento de Bioquímica da Universidade Estadual de Londrina.

3 Docente do Departamento de Tecnologia de Alimentos e Medicamentos da Universidade Estadual de Londrina.

* Autor para correspondência.
} 


\section{Generalidades}

O Brasil ocupa posição de destaque na produção de café, representada por aproximadamente $26 \%$ de exportação do produto no mercado internacional. A cifra de exportação atingiu 21,4 milhões de sacas $(60 \mathrm{Kg})$ em 2001, com receita cambial de US\$1,4 bilhões (ABECAFE, 2002; ABIC, 2002). Aliado ao título de maior produtor e exportador mundial, o país também detém a fama de maior mercado consumidor de café (TOLEDO, 2000; LEONI et al., 2001).

A cafeicultura brasileira produziu 35,$3 ; 26,6$ e 28,2 milhões de sacas nas safras de 1998/99, 1999/ 2000 e 2001/2002, respectivamente. A estimativa inicial da produção de 2002/2003, ampliada para 37,6 milhões de sacas, com a participação do Paraná em 1,6 milhões de sacas correspondentes a 4,3\% da produção nacional, classificou o Estado no quarto maior produtor de café brasileiro (ABECAFE, 2002). Entre os tipos de café cultivados e utilizados para a comercialização no Brasil (Coffea arabica e C. robusta), o Estado do Paraná produz C. arabica (PETTIGREW, 1999).

Os frutos de café estão expostos à contaminação por uma variedade de microrganismos, principalmente de fungos capazes de afetar fases de pré e pós colheita, resultando em perda no rendimento, descoloração, redução do valor nutricional e contaminação por micotoxinas (SOUZA; CARVALHO, 1997). A intensidade e diversidade da micobiota, assim como a subsequente produção de toxinas são condicionadas pelas etapas de colheita, preparo, transporte e armazenamento (TANIWAKI; BANHE; IAMANAKA, 1998, 1999; URBANO et al., 2001), associadas a condições ambientais que prevalecem nas regiões produtoras durante o ciclo produtivo (SOUZA; CARVALHO,1997; HUSSEIN; BRASEL, 2001).

A ocorrência de Alternaria spp., Fusarium spp., Cladosporium spp., Colletotrichum spp., Phoma spp., Mucor spp., Khuskia spp., Aspergillus niger, Aspergillus ochraceus, Aspergillus carbonarius e Penicillium spp., constatada nos distintos estágios produtivos de café no Estado de São Paulo e cerrado mineiro, evidenciou a susceptibilidade fúngica dos grãos de café nas diferentes fases do desenvolvimento, desde a planta até o armazenamento. O potencial toxigênico foi detectado em isolados de $A$. ochraceus, A. carbonarius e $A$. niger (TANIWAKI; BANHE; IAMANAKA, 1998, 1999, TANIWAKI; PITT; TEIXEIRA, 2000).

A análise de microbiota fúngica, em café proveniente de 31 países produtores, demonstrou a predominância de Aspergillus spp. (A. ochraceus, A. flavus, $A$. versicolor, $A$. niger, $A$. tamarii e A. wentii) e Penicillium spp. (P. cyclopium, $P$. citrinum e $P$. expansum (MISLIVEC, 1983). O monitoramento confirmou a pesquisa anterior desenvolvida por Levi, Trenk e Mohr (1974), que detectaram predomínio de $A$. ochraceus, A. flavus, A. niger, A. glaucus, $A$. candidus e Penicillium spp. em amostras de café verde oriundas de diferentes países. Urbano et al. (2000, 2001) constataram alto nível de contaminação fúngica, incluindo Penicillium spp., Cladosporium spp., Fusarium spp., Rhizopus spp. e Aspergillus spp., em café brasileiro analisando diferentes estádios de maturação e processamento. $\mathrm{O}$ gênero Aspergillus representou 33,2\% da micobiota, sendo $10,3 \%$ referente a $A$. ochraceus e $22,9 \%$ a $A$. niger, com a maioria das cepas toxigênicas isoladas de amostras obtidas no terreiro e na tulha.

Alguns autores encontraram uma correlação positiva entre a ocorrência de fungos, local de cultivo e diferentes estádios de maturação de café. $O$ fato indica que fatores ambientais e características inerentes do substrato, aliados à interação fúngica no mesmo nicho determinam a espécie dominante, alterando os padrões de crescimento fúngico e produção de micotoxinas (NORTHOLT; BULLERMAN, 1982; ALVES; CASTRO,1998; LEE; MAGAN,1999; HUSSEIN; BRASEL, 2001).

Embora a contaminação fúngica e de micotoxinas em produtos agrícolas sejam inevitáveis e de difícil controle, medidas preventivas se baseiam no estudo de fatores bióticos e abióticos no crescimento fúngico e produção de toxinas. Ênfase tem sido dada à 
composição de substrato e interação microbiana, caracterizada pela competição e inibição devido a produção de metabólitos capazes de exercer antibiose (NORTHOLT; BULLERMAN, 1982; PASTER; PUSHINSK; MENASHEROV,1992; HUSSEIN; BRASEL, 2001).

A micologia em café, inicialmente concentrada no estudo da perda de qualidade sensorial (SOUZA; CARVALHO, 1997; PETRACCO, 1998), sofreu redirecionamento devido a constatação freqüente da ocorrência de A. ochraceus potencialmente produtor de uma micotoxina nefrotoxigênica denominada de ocratoxina A (ALVES; CASTRO, 1998; PETRACCO, 1998; LEE; MAGAN, 1999). Assim, a qualidade do produto confronta diretamente com a fitossanidade vegetal, sendo esta a causa de repercussão direta na economia do país e saúde do consumidor (PETRACCO, 1998).

A detecção do fator de toxidez/patogenia microbiana, seja para o controle de qualidade ou biocontrole, depende essencialmente de métodos analíticos capazes de direcionar de maneira adequada as decisões e medidas a serem adotadas. A cromatografia líquida de alta eficiência (CLAE), cromatografia de camada delgada (CCD) e o imunoensaio "enzyme linked immunosorbent assay" (ELISA) destacam-se entre os métodos desenvolvidos para proceder análises quantitativa e qualitativa de toxinas de origem biológica em produtos agrícolas, constituindo eficiente programa de monitoramento da exposição humana e animal. O ensaio imunoenzimático ELISA surgiu como um método analítico rápido promissor para a detecção de toxinas e microrganismos patogênicos em alimentos.

Em vista disto, uma explanação integrando principal resistência natural de café / microbiologia com metodologia analítica constituiria na ferramenta básica fundamental para avançar no seguimento na área de segurança alimentar.

\section{Cafeína: fatores naturais no controle de fungos}

A busca por qualidade em produtos agrícolas estimulou a pesquisa sobre fontes de controle em fitopatógenos e fungos toxigênicos, visando minimizar produção de toxinas nas etapas de pré e pós colheita. Os fungicidas químicos destacaram-se pela ação preventiva e rápida (PRUSKY, 1996; FRANCESCHINI et al., 2001). Entretanto, o espectro não abrange todas as espécies patogênicas, aliado ao aumento cada vez maior de resistência microbiana contra agentes químicos (WILLET; KUPFERMAN, 1992; FRANCESCHINI et al., 2001). Entre os mecanismos envolvidos citam-se a diminuição de permeabilidade membranar, aquisição de capacidade de detoxicação celular, ou modificação no sítio de ligação membranar ao fungicida (TUYL, 1997). Aliada a indução de resistência microbiana, o uso indiscriminado de fungicidas químicos na agricultura representa perigo à saúde, devido a persistente contaminação por resíduos no meio ambiente (DEKKER; GEORGOPOULOS, 1982; SPOTS; CERVANTES, 1986; FRANCESCHINI et al., 2001).

A conscientização sobre os riscos do emprego de controle químico intensificou a pesquisa, em busca de novas alternativas seguras à saúde e ecossistema. Antimicrobianos clássicos, empregados na tecnologia de alimento, pertencentes a categoria de benzoatos, sorbatos, ácidos orgânicos, dióxido de enxofre, sulfitos, nitrito e compostos fenólicos apresentam uso restrito (DAFFRE et al., 2001). Além disto, a desvantagem de determinados compostos do grupo está no caráter carcinogênico, assim como e a possibilidade de reação com macromoléculas constituintes de alimento, não se descartando a capacidade metabólica de microbiota na inativação de antimicrobiano (DAFFRE et al., 2001).

Neste contexto, o controle biológico de espécies patogênicas à planta e humanos surgiu entre os métodos alternativos de escolha, já que a ação através de antibiose, competição por nutrientes e crescimento celular permitem minimizar o impacto ambiental e resistência fúngica (TAVARES, 1996; 
FRANCESCHINI et al., 2001). As dificuldades referentes a modalidade consistem no alto custo de implantação, aliada a inconstância na manutenção de linhagens microbianas melhoradas, devido a perda de características iniciais (TAVARES, 1996).

Atualmente, a modificação genética de matéria prima vem se destacando entre os métodos de controle dos fitopatógenos (MUNKVOLD; HELLMICH; RICE, 1999). Entretanto, a técnica é onerosa, além da necessidade de laboratórios equipados e estudo a longo prazo, sendo os efeitos adversos resultantes da ingestão de produtos transgênicos, um assunto bastante polêmico (MUNKVOLD; HELLMICH; RICE, 1999).

$\mathrm{O}$ desenvolvimento de fungos toxigênicos e subsequente síntese de metabólitos tóxicos dependem da composição química natural de substrato (SCUSSEL, 1998). As plantas sintetizam compostos orgânicos denominados de metabólitos secundários, aparentemente sem utilidade para o crescimento, referente ao desenvolvimento estrutural. Não obstante, o enfoque atual concentra-se na identificação destes produtos de ocorrência natural devido ao caráter bioativo, estando entre as atividades mais exploradas, o efeito protetor contra predadores e infecção por patógenos microbianos (TAIZ; ZEIGER, 1998).

Os principais grupos de metabólitos secundários resumem-se em compostos terpênicos, fenólicos e nitrogenados (alcalóides) caracterizados pela ampla aplicação prática, em virtude de atividades biológicas; sendo bastante atraente a possibilidade de uso comercial como defensivos (fungicidas, inseticidas), produtos farmacêuticos e flavorizantes (TAIZ; ZEIGER, 1998). Na categoria de metabólitos naturais também incluem os peptídeos antimicrobianos de amplo espectro de ação contra bactérias, fungos, vírus e parasitas, motivo desencadeador de atual corrida por pesquisa em compostos bioativos (DAFFRE et al., 2001).

A cafeína aponta entre os componentes naturais com possível atividade inibitória no crescimento de fungos toxigênicos e na produção de micotoxinas.
Em café, este composto inerente participa entre compostos que conferem ao produto a característica de baixa ocorrência e grau de contaminação de micotoxinas (BUCHANAN; FLETCHER, 1978; BUCHANAN; TICE; MARINO, 1981, BUCHANAN; HOOVER; JONES, 1983).

A cafeína (1,3,7 trimetilxantina) pertence ao grupo de alcalóides naturais que confere efeito estimulante à bebida (NAIK; NAGALAKSHMI, 1997). Quimicamente, consiste de uma xantina ligada a três grupos metila através de seus átomos de nitrogênio, sendo caracterizada por alta estabilidade térmica (FRANÇA et al., 2001). Além de exercer efeito protetor à planta, a cafeína atua como molécula armazenadora de nitrogênio por ser um composto nitrogenado (MAZZAFERA; YANO; VITÓRIA, 1996).

O teor de cafeína em grãos de café diminui durante o processo de maturação, cujo valor máximo $(0,9 \%)$ pertence ao estádio verde e o mínimo $(0,58 \%)$, ao estádio passa. A redução de fatores de defesa no decorrer do amadurecimento contribui negativamente na proteção contra ataque fúngico (PIMENTA; COSTA; CHAGAS, 2000; GRIGOLI, 2001).

A atividade inibitória de cafeína foi constatada no crescimento de Aspergillus spp. (A. ochraceus, A. flavus, A. versicolor) e Penicillium spp. ( $P$. expansum, $P$. urticase, P. roquefortii) (BUCHANAN; FLETCHER., 1978, BUCHANAN; TICE; MARINO, 1981, BUCHANAN; HOOVER; JONES, 1983; CHALFOUN; PEREIRA; ANGÉLICO, 2000). O efeito caracterizou-se pela ação pouco significativa no desenvolvimento fúngico inicial ( 5 dias), seguido de elevação no grau de inibição na fase estacionária (10 dias). $\mathrm{O}$ fato do efeito ser proporcional à dose de cafeína, evidenciou a atividade biológica como possível agente fungistático de ocorrência natural no café (BUCHANAN; FLETCHER. 1978; BUCHANAN; TICE; MARINO, 1981; BUCHANAN; HOOVER; JONES, 1983; CHALFOUN; PEREIRA; ANGÉLICO, 2000).

A cafeína inibiu $98 \%$ da produção de ocratoxina 
A em A. ochraceus NRRL 3174 isolado de cereais, sendo que esta característica inibitória na produtividade ocorreu em maior intensidade, do que o efeito sobre desenvolvimento de mesmo fungo (BUCHANAN; TICE; MARINO, 1981). Resultados similares foram obtidos por Tsubouchi et al. (1985), que também constataram inibição simultânea no crescimento e produção de OTA em $A$. ochraceus IFM 0458 isolado de arroz. Embora a cafeína iniba crescimento fúngico e produção de micotoxinas, ambos os processos provavelmente não estejam diretamente relacionados, i.e, mecanismos envolvidos sejam distintos (BUCHANAN; TICE; MARINO, 1981; BUCHANAN; HOOVER; JONES, 1983; CHALFOUN; PEREIRA; ANGÉLICO, 2000). A inibição no crescimento micelial sem afetar a toxigenicidade provavelmente esteja associada à alteração no metabolismo de purinas, em decorrência da similaridade estrutural entre purinas (nucleosídeos e nucleotídeos) e cafeína. O fato resulta na inibição competitiva de atividade enzimática, na síntese de ácidos nucléicos (BUCHANAN; TICE; MARINO, 1981; BUCHANAN; HOOVER; JONES, 1983). Referente ao efeito inibitório de cafeína sobre produção de OTA, Buchanan e Fletcher (1978), Buchanan, Tice e Marino (1981), Buchanan, Hoover e Jones (1983) sugeriram ação baseada na atividade sobre fosfodiesterases e síntese de lipídeos.

O domínio sobre mecanismo de ação da cafeína seria útil, quando se pretende elucidar o processo que controla a formação de micotoxinas. Buchanan e Fletcher (1978), Buchanan, Tice e Marino (1981), Buchanan, Hoover e Jones (1983) constataram a característica de alta especificidade, uma vez que compostos relacionados (teofilina e teobromina) exerceram pouco efeito na produção de micotoxinas e crescimento fúngico.

Embora a ação da cafeína seja confirmada, após o período de inibição máxima observou-se redução do efeito, associado à tendência de aumento no crescimento micelial (BUCHANAN; FLETCHER., 1978; BUCHANAN; TICE; MARINO, 1981; BUCHANAN; HOOVER; JONES, 1983). O fato pode ser atribuído à degradação da cafeína, devido a indução de vias capazes de metabolizá-la visando obter fonte de nitrogênio necessária ao desenvolvimento micelial, após o esgotamento de fontes mais simples (ROUSSOS et al., 1994; HAKIL et al., 1998, 1999).

A constatação do potencial na degradação requer análise de cafeína residual, após o crescimento fúngico. Entre os métodos disponíveis, a cromatografia líquida de alta eficiência (CLAE) temse destacado como técnica analítica promissora, capaz de discriminar compostos relacionados, cuja sensibilidade, eficácia e praticidade se sobressaem, quando comparadas a metodologia usual baseada em espectrofotometria (BERG et al., 1984; ROUSSOS et al., 1994; NAIK; NAGALAKSHMI, 1997; ROMANO-MACHADO et al., 1999; BISPO et al., 2002; HORIE et al., 2002).

Tsubouchi et al. (1985) e Hakil et al. (1998) observaram que o potencial de degradação em meio suplementado com cafeína, não é peculiaridade geral de fungos filamentosos, sendo dependentes de cepa. Analisando 20 cepas de fungos filamentosos e fornecendo cafeína como única fonte de nitrogênio, a constatação de crescimento ocorreu apenas em 7 cepas pertencentes a Aspergillus spp. e Penicillium spp., com características diferenciadas na eficiência de assimilação de cafeína (HAKIL et al., 1998). O fato sugere que, a composição química do substrato e características inerentes de cepa fúngica determinaram a capacidade de assimilação de cafeína (ROUSSOS et al., 1995; HAKIL et al., 1999).

Não obstante, o perfil de degradação de cafeína por fungos dependeu da presença de fontes mais simples de nitrogênio, sendo que altas doses de uréia e sulfato de amônia suprimiram a utilização de cafeína (HAKIL et al.,1999). Estes compostos nitrogenados inorgânicos proporcionaram facilidade na assimilação de nitrogênio, aliada a utilização completa de sacarose (fonte de carbono). Todavia, a quantidade reduzida destes componentes permitiu posterior assimilação de cafeína, caso a fonte de carbono não seja limitada (ROUSSOS et al., 1994; HAKIL et al., 1999). O fato foi observado utilizan- 
do meios de cultivo contendo composição variada de compostos nitrogenados, visando isolamento e seleção de cepas fúngicas capazes de degradar a cafeína. Cepas altamente degradadoras foram obtidas em meio contendo cafeína como única fonte de nitrogênio, porém a presença de fontes mais simples provenientes de extratos de café, tornaram as mesmas cepas incapazes de degradar a cafeína (ROUSSOS et al., 1994; HAKIL et al., 1999).

O café contém os mais variados compostos nitrogenados, que desempenham importante função no desenvolvimento de sabor e aroma, citando-se proteínas, enzimas, peptídeos e aminoácidos livres (FRANÇA et al., 2001). Esta disponibilidade alternativa de fontes de nitrogênio inibe a assimilação de cafeína pelos fungos e, mantém seu uso como agente de defesa (ROUSSOS et al., 1995; HAKIL et al., 1999).

Considerando a relevância de $A$. ochraceus e OTA em grãos de café, Tsubouchi et al. (1985) avaliaram duas cepas toxigênicas distintas denominadas de S235-100 e IFM 0458. Os resultados mostraram diferença quanto ao potencial de degradação e grau de inibição pela cafeína, com destaque sobre o efeito na produção de OTA, que foi inibida na cepa IFM 0458, enquanto que na S-235-100 ocorreu estimulação.

\section{Ocratoxina}

A ocratoxina A (OTA) pertence a grupo de metabólito secundário produzido na fase exponencial tardia, ou no início da fase estacionária de crescimento por alguns Aspergillus spp. e Penicillium spp., que freqüentemente contaminam o café e ampla variedade de cereais (Moss, 1996; Larsen et al., 2001). A. ochraceus e $P$. verrucosum representam as principais espécies produtoras, sendo que se diferenciam nas condições ótimas de temperatura, $\mathrm{pH}$, atividade de água e necessidades nutricionais para o crescimento e produção de OTA (MOSS,1996; TRUCKSESS et al.,1999; SWEENEY; WHITE; DOBSON, 2000).
Quimicamente, a OTA (7-[L-bfenilalanilcarbonil]carboxil-5-cloro-8 hidroxi-3,4 diidro-3R metilisocumarina) consiste de uma diidroisocumarina ligada através de seu grupo 7 carboxil, por uma ligação amida, à L-fenilalamina (XIAO et al., 1995; TRUCKSESS et al.,1999). Sendo uma molécula de polaridade média e alta estabilidade térmica, caracteriza-se pela presença de grupos cromóforos com propriedades fluorescentes sob luz UV a 335nm (BLANC et al., 1998; PETRACCO, 1998). Por outro lado, o caráter isocumarina da molécula e o grupo carbonil lactona conferem a atividade tóxica (XIAO et al.,1996; PETRACCO, 1998).

Entre as ocratoxinas e análogos que compõem o grupo, a literatura relata ocorrência de ocratoxina $\mathrm{A}$, ocratoxina $\mathrm{B}$, ocratoxina $\mathrm{C}$, ocratoxina a, metiléster de Oa, 4-hidroxi-OTA e outros (XIAO et al., 1995; KAWAMURA et al.,1989). OTA destaca-se pela maior toxicidade e ocorrência natural em produtos vegetais, envolvendo-se em intoxicações clínicas e subclínicas em animais e na etiologia de doenças humanas (KAWAMURA et al.,1989; FINKGREMMELS; JAHN; BLOM, 1995; MOSS, 1996).

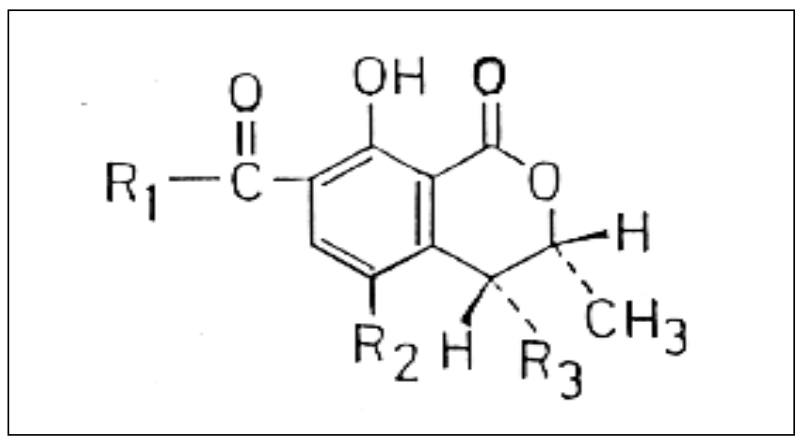

Figura 1 - Estruturas das ocratoxinas e seus análogos. Fonte: Kawamura et al. (1989).

\begin{tabular}{cccc}
\hline Ocratoxinas & $\mathrm{R} 1$ & $\mathrm{R} 2$ & $\mathrm{R} 3$ \\
\hline Ocratoxina A & $\mathrm{C}_{6} \mathrm{H}_{5} \mathrm{CH}_{2} \mathrm{CH}(\mathrm{COOH}) \mathrm{NH}$ & $\mathrm{Cl}$ & $\mathrm{H}$ \\
Ocratoxina B & $\mathrm{C}_{6} \mathrm{H}_{5} \mathrm{CH}_{2} \mathrm{CH}(\mathrm{COOH}) \mathrm{NH}$ & $\mathrm{H}$ & $\mathrm{H}$ \\
Ocratoxina C & $\left.\mathrm{C}_{6} \mathrm{H}_{5} \mathrm{CH}_{2} \mathrm{CHCOO}_{2} \mathrm{C}_{2} \mathrm{H}_{5}\right) \mathrm{NH}$ & $\mathrm{Cl}$ & $\mathrm{H}$ \\
Metilester ocratoxina $\alpha$ & $\mathrm{CH}_{3} \mathrm{O}$ & $\mathrm{Cl}$ & $\mathrm{H}$ \\
4-hidroxi-ocratoxina A & $\mathrm{C}_{6} \mathrm{H}_{5} \mathrm{CH}_{2} \mathrm{CH}(\mathrm{COOH}) \mathrm{NH}$ & $\mathrm{Cl}$ & $\mathrm{OH}$ \\
Ocratoxina $\alpha$ & $\mathrm{OH}$ & $\mathrm{Cl}$ & $\mathrm{H}$
\end{tabular}


A evidência de propriedades toxicológicas da OTA em várias espécies animais se deve a efeitos nefrotóxicos e ação teratogênica, citotóxica, imunotóxica, genotóxica, imunossupressora e possivelmente carcinogênica (FINK-GREMMELS; JAHN; BLOM, 1995; CREPPY, 1999). Os mecanismos envolvidos decorrem da redução na síntese protéica por inibição competitiva na atividade de fenilalanina-RNA-sintetase, devido a semelhança estrutural entre OTA e fenilalanina; inibição de respiração mitocondrial com depleção de síntese de ATP e aumento na peroxidação lipídica (XIAO et al.,1995; MOSS,1996; HOHLER, 1998). Aliado a efeitos primários, o processo de biotransformação hepática da OTA, com formação de intermediários reativos instáveis, emerge como elemento contribuinte na genotoxicidade e mutagenicidade da toxina, cujo mecanismo de ação consiste em ataque direto, ou bioativação de OTA no organismo animal (FINKGREMMELS; JAHN; BLOM, 1995)

A nefrotoxicidade em humanos foi sustentada pela provável associação de OTA com a Nefropatia endêmica dos Balcãs (BEN), uma disfunção renal crônica degenerativa capaz de induzir falência renal, que atingiu população adulta da área rural da região (STUDER-ROHR et al.,1995; PLESTINA, 1996; STOEV, 1998). Pfohl Leszkowicz et al. (2002), baseados na relação entre BEN e tumores do trato urinário, constataram a possível participação de OTA na etiologia de uropatias endêmicas. Atualmente, o envolvimento de OTA em câncer testicular na Europa é sustentado pelo alto consumo de alimentos, considerados como prováveis fontes da toxina na região (SCHWARTZ, 2002). Estas propriedades tóxicas refletiram também em perdas econômicas na avicultura por nefropatia na Bulgária, devido a ração contaminada por OTA e outras micotoxinas (PLESTINA, 1996; ABARCA et al., 2001; STOEV et al., 2002).

Baseado na toxicologia de OTA, aliada a presença inevitável em produtos alimentícios, "Joint FAO/ WHO Expert Committee on Food Additives"-JECFA estabeleceu um limite tolerável provisório de ingestão semanal (PTWI) em 100ng/Kg de peso corpóreo, visando assegurar ausência de efeitos nefrotóxicos (PETRACCO, 1998; LEONI; VALENTE SOARES; OLIVEIRA, 2000). Limites máximos para OTA são regulamentados em diversos países e variam de 1 a $5 \mathrm{ng} / \mathrm{g}$ para alimentos infantis, 2 a $50 \mathrm{ng} / \mathrm{g}$ para cereais e 5 a 300ng/g para rações (VAN EGMOND, 1996). A Organização Mundial da Saúde (OMS) propôs limite de $5 \mathrm{mg} / \mathrm{Kg}$ de OTA em cereais.

A exposição humana decorre da ingestão de uma variedade de alimentos, sendo os cereais e derivados, os principais contribuintes de OTA na dieta (40$50 \%$ de ingestão total), além de fontes secundárias constituídas de produtos cárneos, especiarias, cerveja, vinho, chás, sucos de frutas e café (JORGENSEN, 1998; CHOLMAKOV BODECHTEL et al., 2000; ABARCA et al., 2001; SOLEAS; YAN; GOLDBERG, 2001). Referente a café, a OTA tem sido detectada desde grão verde, a produtos processados e comercializados sob forma de torrado/moído, solúvel e bebida (JORGENSEN, 1998; LEONI; VALENTE SOARES; OLIVEIRA, 2000; PRADO; OLIVEIRA; ABRANTES, 2000; OTTENEDER; MAJERUS, 2001).

Embora o café constitua uma fonte marginal de OTA na dieta, limites para os níveis desta micotoxina nos grãos de café têm sido propostos pela União Européia e adotados por vários países, sendo $8 \mathrm{mg} / \mathrm{Kg}$ para café crú e $4 \mathrm{mg} / \mathrm{Kg}$ para café torrado (HOYLAND et al., 2000). No Brasil, ainda não existe legislação específica definindo OTA em qualquer tipo de alimento ou ração (FURLANI; OLIVEIRA; SOARES, 1999; PRADO; OLIVEIRA; ABRANTES, 2000).

O primeiro relato sobre a incidência de OTA em grãos de café foi publicado por Levi, Trenk e Mohr (1974), reportando-se uma concentração de 30 a $230 \mathrm{mg} / \mathrm{Kg}$ em 5 amostras visivelmente contaminadas. No entanto, análise posterior conduzida em 68 amostras comerciais (sem contaminação visível) revelou baixo nível de contaminação por OTA, indicando que concentrações significativas da toxina seria resultado de intensa proliferação fúngica (LEVI, 1980). 
O alto consumo da bebida de café no Brasil, associado a implicações de OTA na saúde pública e comércio exterior, justificam a importância da pesquisa desta toxina em café brasileiro. Leoni, Furlan e Valente Soares (2001) examinaram a ocorrência de OTA em 132 amostras de café verde provenientes de cinco Estados produtores (Minas Gerais, Paraná, São Paulo, Espírito Santo e Bahia). A análise revelou que $21 \%$ das amostras continham OTA em níveis médios de 7,1 ng/g. Otteneder e Majerus (2001) analisando 613 amostras de grãos de café e produtos derivados comercialmente disponíveis (café torrado, instantâneo e descafeinado), detectaram contaminação por OTA com média de $0,4 \mathrm{ng} / \mathrm{g}$ para grãos de café, $0,6 \mathrm{ng} / \mathrm{g}$ para café torrado, $0,7 \mathrm{ng} / \mathrm{g}$ para café instantâneo e $0,4 \mathrm{ng} / \mathrm{g}$ para descafeinado. Os valores corresponderam a uma ingestão média diária de 9 ng de OTA, extrapolada para um adulto de $70 \mathrm{Kg}$. Salienta-se que estes valores estiveram abaixo do limite tolerável provisório de ingestão diária de 14 ng/Kg p.c., estabelecido pela Codex Alimentarius (JECFA, 1995).

\section{Metodologia analítica para detecção de ocratoxina}

A presença inevitável de fungos em vegetais, associada ao difícil controle de micotoxinas, por serem toxinas naturais, gera dificuldades aos órgãos governamentais e incessáveis discussões internacionais. As medidas efetivas para minimizar a exposição humana, associadas a condições adequadas de produção e processamento dependem de um rigoroso e eficiente programa de monitoramento em produtos agrícolas (CHU, 1984). O desenvolvimento de métodos analíticos com alta sensibilidade, especificidade, viabilidade, rapidez, reprodutibilidade e facilidade de uso, além de exatidão e precisão é essencial na micotoxicologia para avaliar exposição humana e animal (CHU, 1984).

No entanto, devido a características estruturais e distribuição heterogênea de micotoxinas nos produtos alimentícios, a condução de análise depara com três principais problemas: a) diversidade nas estruturas químicas inerentes de micotoxinas exige individualização no desenvolvimento metodológico para cada grupo de moléculas; b) determinado o procedimento para a detecção, o nível de separação/diferenciação deve ser capaz de detectar análogos de micotoxinas estruturalmente relacionados; c) distribuição heterogênea de micotoxinas nos produtos agrícolas exige análise de um número significativo de amostras, visando minimizar a variabilidade estatística (DAVIS et al., 1980).

Os métodos desenvolvidos para a detecção de micotoxinas incluem procedimentos químicos e biológicos, agrupados em cromatografia em camada delgada (CCD), cromatografia líquida de alta eficiência (CLAE), cromatografia gasosaespectrofotometria de massa (GC-MS) (AOAC, 1995; LARSEN; SVENDSEN; SMEDSGAARD, 2001; SOLEAS; YAN; GOLDENBERG, 2001) e diferentes modalidades de ensaio imunoenzimático, com ênfase a cromatografia de imunoafinidade e "indirect competitive enzyme immunosorbent assay" - IC-ELISA (CHU, 1984; PESTKA; ABOUZIED; SUTIKNO, 1995; BARNA-VETRO et al., 1996; SCOTT; TRUCKSESS, 1997; UENO et al., 1998; NAKAJIMA, 1999; TRUCKSESS, 2000). Referente à OTA em café, as técnicas analíticas propostas para a determinação incluem CLAE, CCD, fluorimetria, cromatografia de afinidade e ELISA (KAWAMURA et al.,1989; MARTINS et al., 2000; TRUCKSESS, 2000).

A confirmação química de micotoxinas detectadas em amostras é essencial para minimizar resultados falsos. A coincidência dos aspectos visíveis ou das propriedades cromatográficas não garante, que o composto isolado do extrato seja quimicamente idêntico à referência (padrões). Entre as técnicas disponíveis destacam-se a espectrofotometria de massa de alta resolução, ressonância magnética nuclear, mudança de fase móvel, derivatização e cocromatografia (JIAO et al., 1992; INSTITUTO ADOLFO LUTZ, 1998). 
Embora a CCD conste em "Association of Official Analytical Chemists" (AOAC, 1995) entre os métodos recomendados para detectar OTA em grãos de café verde, sua baixa sensibilidade com limite de detecção de $20 \mathrm{ng} / \mathrm{g}$ (AOAC, 1995), ou 10 ng/g (SOARES; RODRIGUEZ AMAYA, 1985; PITTET; ROYER, 2002), torna ineficaz perante os níveis máximos propostos pela Organização Mundial da Saúde $(5 \mathrm{ng} / \mathrm{g})$ e para a aplicação em café torrado e derivados (máximo de $4 \mathrm{ng} / \mathrm{g}$ ). O fato evidencia a necessidade de CLAE para análise quantitativa de ocratoxinas, assim como outros métodos que apresentem eficiência equivalente (AOAC, 1995; FURLANI; OLIVEIRA; SOARES, 1999).

A CLAE consiste de técnica de separação tradicional destinada à análise quantitativa (CHU, 1984; COLLINS; GUIMARÃES, 1993). O uso de colunas analíticas preenchidas com partículas adsorventes à base de sílica contendo fase estacionária, acopladas a uma fase móvel eluída sob alta pressão e sistemas detectores de fluorescência e UV, proporcionam quantificação com alta sensibilidade e reprodutibilidade (CHU, 1984; COLLINS; GUIMARÃES, 1993). A CLAE é uma metodologia sensível de alta resolução, cuja eficiência depende da etapa de pré-limpeza da amostra, tornando indispensável o emprego de minicolunas para a remoção de impurezas e concentração de ocratoxinas no extrato bruto (CHU, 1984; COLLINS; GUIMARÃES, 1993). Além dos procedimentos convencionais de limpeza, a CLAE requer tempo de análise significativo, técnicos treinados e alto custo de equipamento e manutenção, restringindo o emprego em laboratórios de rotina (CHU, 1984; COLLINS; GUIMARÃES, 1993; BARNA-VETRO et al.,1996).

Em suma, a detecção de micotoxinas em matrizes alimentares, que já é de natureza complexa, exige limpeza extrema de interferentes contidos na amostra para prosseguir com análise cromatográfica empregando CLAE. I.e, a eficiência na determinação é dependente do processo de limpeza do extrato (VAN EGMOND, 1991; SCOTT; TRUCKSESS, 1997; MATEO et al., 2001; LLORENS et al., 2002).
Visando atender a necessidade, diferentes técnicas de purificação, seja clássicas empregando clarificação e partição líquido-líquido como envolvendo colunas de extração em fase sólida (sílica, octadecilsilil e imunoafinidade) emergiram como técnicas de limpeza e purificação na análise de micotoxinas (VAN EGMOND, 1991; PESTKA; ABOUZIED; SUTIKNO, 1995; SCOTT; TRUCKSESS, 1997; SOLFRIZZO; AVANTAGGIATO; VISCONTI, 1998; FURLANI; OLIVEIRA; SOARES, 1999).

Desenvolvimento de colunas eficazes, capazes de atingir o nível de separação e purificação em apenas uma etapa cromatográfica, tem sido desafio constante na metodologia analítica. Com este intuito, a literatura descreveu diversos tipos de minicolunas compostas de diferentes materiais de preenchimento, como $\mathrm{C}_{18}$, QMA, sílica (Waters ${ }^{\circledR}$ ); SAX, Bond Elut DEA e PSA (Varian $\left.{ }^{\circledR}\right)$; colunas HBL Oasis ${ }^{\circledR}$ (Waters ${ }^{\circledR}$ ) (TERADA et al., 1986; KAWAMURA et al., 1989; AKIYAMA et al., 1997; MATEO et al., 2001; DE GIROLAMO et al., 2001; LLORENS et al., 2002). Estas minicolunas preparadas com sílica, octadecilsilil, florisil, cianopropil ou celite, constituiram a base para a introdução de ferramenta biológica na metodologia analítica, iniciando-se a implementação da coluna de imunoafinidade (TERADA et al., 1986; SCOTT; TRUCKSESS, 1997; AKIYAMA et al., 1997; SOLFRIZZO; AVANTAGGIATO; VISCONTI, 1998; MATEO et al., 2001; LLORENS et al., 2002). A técnica de cromatografia de afinidade pode ser considerada como uma inovação na área de metodologia analítica, essencialmente baseada em procedimentos químicos, já que a imunoafinidade introduziu componente biológico como o reagente principal na análise (OSTROVE, 1990; SCOTT; TRUCKSESS, 1997; NAKAJIMA, 1999). A combinação sequencial de diferentes colunas tem sido utilizada na purificação de extratos. Entwisle et al. (2001) utilizaram sequência de colunas de fenilsilil e imunoafinidade para análise de OTA por CLAE em café torrado, obtendo-se recuperação de 65 a 97\%. 
As colunas de imunoafinidade (CIA), preparadas com anticorpos anti-micotoxinas, destacam-se por conferir rapidez, simplicidade, alta especificidade e recuperação, melhorando limites de detecção; uma vantagem incontestável também está na utilização de tampão, dispensando o emprego de grandes volumes de solventes tóxicos durante o preparo. As colunas compõem-se de um suporte de fase sólida ativada (Sepharose ${ }^{\circledR} \mathrm{CNBr}$ ), no qual imobilizam-se os anticorpos específicos contra determinada micotoxina (OSTROVE, 1990; SCOTT; TRUCKSESS, 1997; NAKAJIMA, 1999). O processo de limpeza consiste na ligação seletiva de micotoxinas presentes no extrato aos anticorpos da coluna, seguido de eluição com solvente apropriado.

As distintas técnicas de purificação foram avaliadas quanto a determinação de OTA em café e outros produtos alimentícios (SOLFRIZZO; AVANTAGGIATO; VISCONTI, 1998; CASTELLARI et al., 2000; JORNET; BUSTO; GUASH, 2000; ENTWISLE et al., 2001). Os resultados indicaram que a coluna de imunoafinidade (CIA) apresentou maior eficiência na remoção de interferentes existentes nos extratos alimentares, aumentando o limite de detecção de OTA por CLAE. Para a análise de OTA, encontram-se disponíveis colunas de imunoafinidade comerciais a exemplo de Ochratest (Vicam ${ }^{\circledR}$ ); Ochraprep, Ochrastand, Ochrascan (Rôhne Diagnostics $\left.{ }^{\circledR}\right)$. Existe ainda a possibilidade de preparo de colunas a partir da produção de anticorpos monoclonais específicos (SCOTT; TRUCKSESS,1997; CASTELLARI et al., 2000; HOYLAND et al., 2000; ENTWISLE et al., 2001).

Embora a CIA comercial caracteriza-se por alto custo, a desvantagem tende a ser minimizada pelo processo de regeneração adequado da coluna, que permite reutilização sem perdas significativas na atividade, reduzindo o custo das análises (NAKAJIMA, 1990; SCOTT; TRUCKSESS, 1997; FURLANI; OLIVEIRA; SOARES,1999)

Nakajima (1990) foram os pioneiros na utilização de CIA na etapa de limpeza para análise cromatográfica de OTA em grãos e produtos de café. A metodologia desenvolvida consistiu de técnica sensível, específica e rápida para detectar toxinas em matrizes de difícil análise por procedimentos convencionais, cuja sensibilidade atingiu limite de detecção de $0,5 \mathrm{ng} / \mathrm{g}$ para café em grão e solúvel, com recuperação acima de $98 \%$. Mais recentemente, Pittet et al. (1996) associando CIA a CLAE, obtiveram cromatogramas sem interferentes na região de Rf próxima a OTA, com limite de detecção de $0,2 \mathrm{ng} / \mathrm{g}$ em café verde/torrado, com recuperação acima de $80 \%$.

\section{Imunoensaios para a detecção de ocratoxina A}

Embora as técnicas analíticas convencionais (CCD, CLAE, GC) sejam oficialmente aceitas e validadas, o alto custo de instrumentação e manutenção, consumo de tempo, exigência de extrema purificação/limpeza de amostra e treinamento técnico, restringem o uso em rotina laboratorial (CHU, 1984; CHU et al., 1988; PESTKA; ABOUZIED; SUTIKNO, 1995; BARNA-VETRO et al.,1996).

Em vista a estas dificuldades e obstáculos eminentes, o ensaio imunoquímico constituiu técnica útil na análise de micotoxinas, com ênfase ao ensaio imunoenzimático "enzyme linked immunosorbent assay” (ELISA), caracterizado por reações imunológicas de alta especificidade e sensibilidade (NEWSOME, 1986; VOLLER; BIDWELL, 1986). A técnica vem se destacando entre os métodos analíticos alternativos promissores para a detecção e quantificação de ocratoxinas em alimentos, despertando interesse na produção de anticorpos específicos para a condução da análise (CHU, 1984; HEFLE, 1995; PESTKA; ABOUZIED; SUTIKNO, 1995; BARNA-VETRO et al., 1996; SIBANDA et al., 2001).

A OTA (MM=403,82Da) mostra-se incapaz de estimular o sistema imune para produzir anticorpos, devido a estrutura relativamente pequena. Não obstante, torna-se imunogênica após conjugação de grupo carboxila ativo na molécula com os grupos amino de proteínas carreadoras de alta massa 
molecular, empregando sistema de ativação via carbodiimida ou anidrido (CHU, 1984; NEWSOME, 1986; KAWAMURA et al., 1989; GAZZAZ; RASCO; DONG, 1992; HEFLE, 1995; XIAO et al., 1995). Consequentemente, o preparo de antígeno para imunização (hapteno) requer suporte peptídico pouco imunogênico, para obtenção de anticorpos monoclonais e policlonais específicos.

Kawamura et al. (1989) prepararam 7 anticorpos monoclonais para OTA e designaram de MAbs OTA.1,2,3,4,5,6 e 7, utilizando albumina do soro bovino (BSA) como proteína carreadora e adjuvante. As respectivas especificidades do anticorpo foram determinadas procedendo-se "indirect competitive ELISA" (IC-ELISA). Os anticorpos MAbs OTA.1,3,4,5 e 7 apresentaram reatividade cruzada com OTA (100\%) e OTC (63,1-99,5\%), enquanto que reagiram fracamente com os análogos OTB (0,63-1,14\%), OTa $(0,04-0,07 \%)$ e 4-hidroxi OTA (1,19-1,51\%), evidenciando a especificidade do ensaio imunológico à OTA. Os resultados sugeriram que o resíduo L-fenilalanina, cloreto e hidrogênio nas respectivas posições $C_{12}\left(R_{1}\right), C_{5}\left(R_{2}\right)$ e $C_{4}\left(R_{3}\right)$ na molécula de OTA, conforme Figura 3, exerceu grande influência na interação entre OTA e estes anticorpos. $\mathrm{O}$ anticorpo MAb OTA.2 reagiu igualmente com OTA e OTB, indicando que a presença de cloreto na posição 5 da molécula da toxina não atuou como epitopo neste anticorpo. O limite de detecção para OTA por ELISA competitivo indireto (IC-ELISA) utilizando MAb OTA.1 e OTA.7 foi de $50 \mathrm{pg} / \mathrm{mL}$, evidenciando a alta sensibilidade dos anticorpos (KAWAMURA et al., 1989).

Candlish, Stimson e Smith (1988) produziram anticorpos monoclonais em camundongos imunizados com o conjugado OTA-KLH ("keyhole limpet hemocyanin") e obtiveram reatividade cruzada de 8,2\% para OTC, empregando ELISA competitivo indireto (IC-ELISA). A ausência de reação significativa do anticorpo com outros análogos, micotoxinas e interferentes indicou a alta especificidade deste anticorpo à OTA.
Gyöngyösi-Horvath, Barna-Vetró e Solti (1996) também prepararam anticorpos monoclonais contra OTA com sensibilidade em níveis de picogramas, empregando ELISA competitivo direto com alta especificidade, reatividade cruzada limitada a OTB $(9,3 \%)$ e limite de detecção de 42 pg/mL.

A qualidade do anticorpo (alta afinidade e especificidade, baixa reatividade cruzada) é essencial para o desenvolvimento de imunoensaios sensíveis para a micotoxicologia, já que estas técnicas baseiam-se na interação específica entre antígenoanticorpo (RITCHIE, 1986; GAZZAZ; RASCO; DONG, 1992; HEFLE, 1995; BARNA-VETRO et al., 1996). A obtenção de anticorpos de alta qualidade depende de imunógenos purificados, protocolo de imunização e critério para seleção de monoclonais específicos (NEWSOME, 1986; BARNA-VETRO et al., 1996; HEFLE, 1995). Os anticorpos monoclonais caracterizam-se pela uniformidade, alta especificidade e afinidade constante a um único epitopo, sendo homogêneos em estrutura e especificidade, características estas essenciais na identificação de antígenos em matrizes complexas (GAZZAZ; RASCO; DONG, 1992; HEFLE, 1995; DIETRICH et al., 1995).

Entretanto, a análise por ELISA limita-se a determinados tipos de alimentos, em vista ao efeito de matrizes que resultam em interferência nas reações imunológicas, i.e, interações inespecíficas de anticorpo a componentes alimentares (proteínas, ácidos graxo) ou bloqueio estérico superestimariam a concentração da micotoxina, ou resultariam em reação falso-positiva (PESTKA et al., 1994; PESTKA; ABOUZIED; SUTIKNO, 1995; HEFLE, 1995; BARNA-VETRO et al., 1996). Consequentemente, a vantagem na eliminação da extensiva etapa de prélimpeza ostentada pelo ELISA, resulta na permanência de constituintes alimentares inconvenientes, capazes de reagir/adsorver com os anticorpos (PESTKA et al., 1994; BARNA-VETRO et al., 1996). O fato acentua a resposta inibitória no imunoensaio por competição, afetando o sítio de li- 
gação do anticorpo (PESTKA et al., 1994; BARNAVETRO et al., 1996). Esta inespecificidade pode ser minimizada diluindo-se o extrato, ou adotando processo simples de limpeza (PESTKA; ABOUZIED; SUTIKNO, 1995; HEFLE, 1995; ONO et al., 2000). Deve-se considerar também o efeito de precursores de micotoxinas ou produtos oriundos do metabolismo fúngico, capazes de interferir na reação imunológica. Outra desvantagem associada a técnica resume-se no emprego de reagentes imunológicos (material biológico), cujo componente fundamental, a imunoglobulina apresenta baixa estabilidade com possível perda de reatividade, exigindo manutenção adequada, fator decisivo na confiabilidade da reação (DAUPHINAIS, 1986; NEWSOME, 1986; HEFLE, 1995).

Apesar de críticas e limitações, o ensaio imunoquímico na micotoxicologia vem gradativamente ocupando o espaço (HEFLE, 1995; PESTKA; ABOUZIED; SUTIKNO, 1995). Aliada a vantagem em analisar e detectar concentrações traço de um composto (pg), a metodologia emprega procedimento com pouca ou nenhuma necessidade de purificação e/ou concentração de analito (GAZZAZ; RASCO; DONG, 1992; HEFLE, 1995; PESTKA; ABOUZIED; SUTIKNO, 1995; GARTHWAITE, 1999). Teoricamente, o descarte da etapa de clarificação deve-se ao caráter altamente específico das interações imunológicas, somada à sensibilidade na detecção de interações antígeno-anticorpo, ampliada pela reação enzimática (DAUPHINAIS, 1986; HEFLE, 1995). A técnica baseia-se na detecção de produto cromóforo resultante da reação enzimática, pela espectrofotometria, sendo esta medida, a base para quantificação do anticorpo (NEWSOME, 1986; GAZZAZ, RASCO; DONG, 1992; HEFLE, 1995; GARTHWAITE, 1999).

A enzima marcadora peroxidase é a mais empregada na detecção de micotoxinas (GAZZAZ, RASCO; DONG, 1992). Assim, os kits comerciais Veratox (Neogen $\left.{ }^{\circledR}\right)$ e Ochracard (Rohne Diagnostics $\left.{ }^{\circledR}\right)$ costumam empregar o sistema peroxidase- $\mathrm{H}_{2} \mathrm{O}_{2}$-cromóforo, em vista de alto "turn over" enzimático, estabilidade e capacidade de fornecer produto cromóforo em quantidade extremamente sensível, proporcional a quantidade de conjugado anticorpo-enzima presente (MARTINS et al., 2000). Aliada às vantagens mencionadas, a simplicidade de operação, rapidez de análise, reprodutibilidade, necessidade de pequeno volume de amostra, limite de detecção, baixo custo após a padronização do ensaio e potencial de triagem em campo, comparado aos métodos analíticos convencionais emergem como características destacáveis do ensaio imunoenzimático (SAMARAJEEWA et al., 1991; HEFLE, 1995; PESTKA ABOUZIED; SUTIKNO, 1995; BARNA-VETRO et al., 1996; GARTHWAITE, 1999).

Tendo em vista que a baixa massa molecular confere baixa imunogenicidade a micotoxinas, a modalidade de ELISA indicada para proceder a determinação de OTA é o competitivo indireto (ICELISA), que requer apenas um anticorpo específico (CHU, 1984; HEFLE, 1995). Consequentemente, a alta especificidade é fundamental para evitar reações falso positivas, sendo a reatividade do ICELISA dependente exclusivamente de anticorpo primário. O emprego de anticorpo monoclonal (um sítio específico) garante reprodutibilidade, facilitando a padronização e estabilidade do reagente (CHU, 1984; VOLLER; BIDWELL, 1986; HEFLE, 1995; ONO et al., 2000).

O princípio de IC-ELISA baseia-se na competição entre a toxina presente na amostra e àquela adsorvida à microplaca (OTA-BSA), pelo sítio de ligação específico do anticorpo monoclonal (NEWSOME, 1986; GARTHWAITE, 1999). Nesta modalidade do ensaio ELISA, a adsorção do anticorpo à superfície sensibilizada ocorre em proporção inversa a quantidade de analito presente. I.e, a concentração de toxina na amostra é dada indiretamente pela quantificação do anticorpo específico adsorvido, que atua como sítio de ligação ao antiIgG (anticorpo secundário) marcado com enzima responsável pela reação colorimétrica (NEWSOME, 1986; GAZZAZ; RASCO; DONG, 1992; HEFLE, 1995; GARTHWAITE, 1999). 


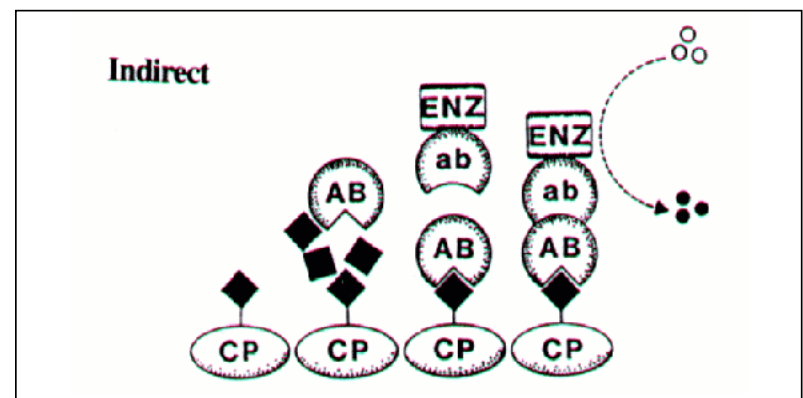

Figura 2 - Princípio de IC-ELISA utilizado para a deteç̧ão de OTA. Fonte: Pestka, Abouzied e Sutikno (1995)

$\mathrm{AB}$ : anticorpo específico à micotoxina; $\mathrm{ab}$ : anticorpo anti IgG conjugado à enzima; $\mathrm{CP}$ : proteína carreadora complexada ao analito.

Em contraste ao preparo de antígeno para imunização, o acoplamento de OTA a microplaca se procede com peptídeo aderente, independente da imunogenicidade, visando obtenção de conjugado estável e economicamente viável (KAWAMURA et al., 1989; NEWSOME, 1986). Conjugados de OTABSA (albumina de soro bovino), KLH ("keyhole limpet hemocyanin") e OVA (ovalbumina) apresentam razão molar de $16.7,19.1$ e 0.3-0.5, respectivamente (KAWAMURA et al., 1989). Embora KLH constitua uma melhor carreadora de OTA, depara-se com alto custo. A OTA-OVA apresenta menor estabilidade em relação ao mesmo reagente preparado com BSA, além de congelamento resultar em perda de atividade. Justifica-se portanto a utilização de BSA, caracterizada pela maior estabilidade, menor custo e eficiência na conjugação com OTA (KAWAMURA et al., 1989).

Os imunoensaios, baseados em ELISA, têm sido desenvolvidos para a quantificação de OTA em diversos produtos agrícolas, exemplificando-se o trigo (LEE; CHU, 1984; KAWAMURA et al., 1989), cevada (KWAK; SHON, 2000), cereais em geral (JARCZYK et al., 1999) e rações (KAWAMURA et al., 1990).

A triagem de OTA em grãos de café por método imunoquímico semiquantitativo foi avaliada por Sibanda et al. (2001), através de desenvolvimento de "flow through enzyme immunoassay", baseado em membrana utilizando anticorpos policlonais antiOTA e conjugado OTA-HRP. A técnica apresentou rapidez e eficiência comparável a CLAE, com a sensibilidade de $8 \mathrm{ng} / \mathrm{g}$, constituindo técnica útil e prática na triagem de OTA em café.

Kawamura et al. (1989) constataram a aplicabilidade e sensibilidade do IC-ELISA para análise de OTA em diferentes produtos (soro, plasma, trigo e carne), obtendo-se um limite de detecção em nível de picogramas, sendo os valores $50,1000,500,200,500$ e $50 \mathrm{pg} / \mathrm{mL}$ obtidos com anticorpos monoclonais MAb OTA.1,2,3,4,5 e 7, respectivamente.

\section{Considerações finais}

Entre as fontes de controle de fungos toxigênicos em produtos agrícolas, os componentes naturais de caráter bioativo constituem alternativa eficaz para minimização de produção de toxinas, com ênfase a cafeína. Todavia, a sua aplicação prática está longe da realidade, devendo-se ancorar a opção da solução imediata do problema sobre monitoramento de toxinas empregando metodologias analíticas eficazes. Os ensaios imunoquímicos apontam entre alternativa atrativa, onde a confiabilidade dos resultados da análise onduzida pelo ELISA deve ser correlacionada com a CLAE. A cromatografia de afinidade é uma inovação na área, que vem sendo amplamente difundida na análise quantitativa de micotoxinas em associação a CLAE e ELISA, já que a associação biológica-química solucionaria as desvantagens descritas sobre cada processo, Sendo assim, o avanço pontual na biotecnologia empregando mecanismos naturais de defesa depende de metodologia analítica, que constitui ferramenta imprescindível na integração das diferentes áreas de ciência básica e aplicada visando segurança e qualidade em alimentos.

\section{Agradecimentos}

À CAPES/MEC (Coordenadoria de Aperfeiçoamento de Pessoa de Nível Superior) pela bolsa de 
Mestrado e CNPq (Conselho Nacional de Pesquisa e Desenvolvimento Científico e Tecnológico) pelo apoio financeiro.

\section{Referências}

ABARCA, M. L. et al. Review: Current inportance of ochratoxin A producing Aspergillus spp. Journal of Food Protection, Des Moines, v.64, n.6, p.903-906, 2001.

AKIYAMA, H. et al. A rapid analysis of ochratoxin A in coffee beans and cereals. Journal of Food Hyg. Soc. Japan, v.38, n.6, p.406-411, 1997.

ALVES, C.; CASTRO, H.A.. Fungos associados ao café (Coffea arabica L.) nas fases de pré e pós-colheita em lavouras da região de Lavras. Summa Phytopathologica, São Paulo, v.24, n.1, p.4-7, 1998.

AOC. Official Methods of Analysis of the Association of Official Analytical Chemists International. Arlington: K. Helrich, 1995.

ABECAFE. Exportações. 2002. Disponível em: <http:// www.abecafe.com.br>. Acesso em: 2003.

ABIC. Exportação. 2002. Disponível em: <http:// www.abic.com.br>. Acesso em: 2003.

BARNA-VETRÓ, I. et al. Sensitive ELISA Test for determination of ochratoxin A. Journal of Agricultural and Food Chemistry, Easton, v.44, p.4071-4074, 1996.

BERG, R. G. et al. Determinação de cafeína em alguns cafés solúveis brasileiros por cromatografia líquida de alta eficiência. Ciência e Tecnologia de Alimentos, Campinas, v.4, n.2, p.116-121, 1984.

BISPO, M. S. et al. Simutaneous determination of caffeine, theobromine and theophyline by high performance liquid chromatography. Journal Chromatographyc Science, Evaston, v.40, n.1, p.45-48, 2002.

BLANC, M. et al. Behavior of ochratoxin A during green coffee roasting and soluble coffee manufacture. Journal of Agricultural and Food Chemisty, Easton, v.46, p.673675, 1998.

BUCHANAN, R. L.; FLETCHER, A. M. Methylxanthine inhibition of aflatoxin production. Journal of Food Science, Chicago, v.43, p.654-655, 1978.

BUCHANAN, R. L.; TICE, G.; MARINO, D. Caffeine inhibition of ochratoxin A production. Journal of Food Science, Chicago, v.47, p.319-321, 1981.

BUCHANAN, R. L.; HARRY, M. A.; GEALT, M. A. Caffeine inhibition of sterigmatocystin, citrinin and patulin production. Journal of Food Science, Chicago, v.48, p.1226-1228, 1983.
BUCHANAN, R. L.; HOOVER, D. G.; JONES, S.B. Caffeine inhibition of aflatoxin : mode of action. Applied and Environmental Microbiology, Washington, v.46, n.5, p.1193-1200, 1983.

CANDLISH, A. A. G.; STIMSON, W. H.; SMITH, J. E. Determination of ochratoxin A by monoclonal antibodybased enzyme immunoassay. Journal of the Association of Official Analytical Chemists, Arlington, v.71, n.5, p.961-964, 1988.

CASTELLARI, M. et al. Comparation of different immunoaffinity clean-up procedures for high performance liquid chromatographic analysis of ochratoxin $\mathrm{A}$ in wines. Journal Chromatography, Amsterdam, v.888, n.1/2, p.129-136, 2000.

COLLINS, C. H.; GUIMARÃES, L. F. L. Cromatografia Líquida de Alta Eficiênica: introdução a métodos cromatográficos. 5.ed. Campinas: UNICAMP, 1993.

CHALFOUN, S. M.; PEREIRA, M. C.; ANGÉLICO, C. L. Efeito da cafeína (1,3,7-triemethylxanthina) sobre o crescimento micelial de fungos associados ao café. Revista Brasileira de Armazenamento, Especial Café, Viçosa, n.1, p.50-53, 2000.

CHOLMAKOV BODECHTEL, C. et al. Ochratoxin A: representative food consumption survey and epidemiological analysis. Archiv. Fuer Lebensmittelhygien, Hannover, v.51, n.4/5, p.111-115, 2000.

CHU, F. S. Immunoassays for analysis of mycotoxins. Journal of Food Protection, Des Moines, v.47, p.562569, 1984.

CHU, F. S. et al. Evaluation by enzyme-linked immunosorbent assay of cleanup for Thin-Layer Chromatography of aflatoxin $\mathrm{B}_{1}$ in corn, peanuts, and peanut butter. Journal of the Association of Official Analytical Chemists, Arlington, v.71, n.5, p.953-956, 1988.

CREPPY, E. E. Human ochratoxicosis. Journal of Toxicology-Toxin Reviews, New York, v.18, n.3/4, p.277293, 1999.

DAFFRE, S. et al. Peptídeos antibióticos. Biotecnologia Ciência \& Desenvolvimento, Brasília, ano 4, n.23, p.4856, 2001.

DAUPHINAIS, R. M. Solving and preventing problems in ligant assay. Section B. Immunoassay. In: ROSE, Noel R. Rose. Manual of clinical laboratory immunolog. 3.ed. Washington: American Society for Microbiology. 1986. Chapter 16, p.88-99.

DAVIS, N.D. et al. Protocols for surveys, sampling, postcollection handling, and analysis of grain samples involved in mycotoxin problems. Journal of the Association of Official Analytical Chemists, Arlington, v.63, n.1, p.95-102, 1980. 
DE GIROLAMO, A. et al. Comparation of different extraction and clean up procedures for the determination of fumonisins in maize and maize based food products. Food Additives and Contaminants, London, v.18, n.1, p.59-67, 2001.

DEKKER, J.; GEORGOPOULOS, S. J. Fungicide resistance in crop protection. Wageningen: Netherlands Center for Agricultural Publishing and Documentation, 1982.

DIETRICH, R. et al. Use of monoclonal antibodies for the analysis of mycotoxins. Natural Toxins, New York, v.3, p.288-293, 1995.

ENTWISLE, A. C. et al. Combined phenylsilane and immunoaffinity collumn cleanup with liquid chromatography for determination of ochratoxin A in roasted coffee: collaborative study. Journal of the Association of Official Analytical Chemists, Arlington, v.84, n.2, p.444-450, 2001.

FINK-GREMMELS, J.; JAHN, A.; BLOM, M. J. Toxicity and Metabolism of Ochratoxin A. Natural Toxins, New York, n.3, p.214-220, 1995.

FRANCESCHINI, M. et al. Biotecnologia aplicada ao controle biológico. Biotecnologia Ciência \& Desenvolvimento, Brasília, ano 4, n.23, p.32-37, 2001.

FRANÇA, A. S. et al. Evolução da composição do extrato de café durante o processo de torrefação. Revista Brasileira de Armazenamento, Especial Café, Viçosa, n.2, p.37-47, 2001.

FURLANI, R. P. Z.; OLIVEIRA, P. L. C.; SOARES, L. M. V. Avaliação de métodos para determinação de ocratoxina A em cafés verdes e torrados. Revista do Instituto Adolfo Lutz, São Paulo, v.58, n.2, p.87-98, 1999.

GARTHWAITE, I. Detection of endophyte toxins by ELISA assay. In: INTERNATIONAL SYMPOSIUM OF MYCOTOXILOGY'99, MYCOTOXIN IN CONTAMINATION: HEALTH RISK AND PREVENTION, 1999, Chiba, Japan. Proceeding ... Chiba, 1999. p.152-159.

GAZZAZ, S. S.; RASCO, B. A.; DONG, F. M. Application of immunochemical assays to food analysis. Critical Reviews in Food Science and Nutrition, Boca Raton, v.32, n.3, p.197-229, 1992.

GRIGOLI, A. A. Fator biológico (microbiota-OTA) versus composição bromatológica no café (cultivares IAPAR-59, CATUAİ, MUNDO NOVO). 2001. Dissertação ( Mestrado em Ciência de Alimentos) - Universidade Estadual de Londrina, Londrina.

GYÖNGYÖSI-HORVÁTH, A.; BARNA-VETRÓ, I.; SOLTI, L. A new monoclonal antibody detecting ochratoxin A at the picogram level. Letters in Applied Microbiology, Oxford, v.22, p.103-105, 1996.
HAKIL, M. et al. Degradation and product analysis of caffeine and related dimethylxanthines by filamentous fungi. Enzyme and Microbial Technology, v.22, n.5, p.355-359, 1998.

HAKIL, M. et al. Caffeine degradation in solid state fermentation by Aspergillus tamarii: effects of additional nitrogen sources. Process Biochemistry, London, v.35, n.1-2, p.103-109, 1999.

HEFLE, S. L. Immunoassay fundamentals. Food Technology, Chicago, v.49, n.2, p.102-107, 1995.

HOHLER, D. Ochratoxin A in food and feed: occurrence, legislation and mode of action. Z. Ernahrungswiss, v.37, n.1, p.2-12, 1998.

HORIE, H. et al. Rapid determination of caffeine in tea leaves. Journal Chromatography A, Amsterdam, v.942, n.1/2, p.271-273, 2002.

HOYLAND, D. et al. Assessmt by Nestlé UK of Ochrascan ${ }^{\circledR}$ a screening test for ochratoxin A in coffee. In: INTERNATIONAL IUPAC SYMPOSIUM ON MYCOTOXINS AND PHYCOTOXINS. 10., 2000, Guarujá. Resumos... Guarujá, 2000. p.27.

HUSSEIN, S. H.; BRASEL, J. M. Toxicity, metabolism and impact of mycotoxins on humans and Animals. Toxicilogy, Limerick, v.167, n.2, p.101-134, 2001.

INTITUTO ADOLFO LUTZ. Secretaria de Estado da Saúde. Secção de Química Biológica/Bioquímica. Micotoxinas. São Paulo, 1998. p.1-42.

JARCZYC, A. et al. Relation between ochratoxin A content in cereal grain and mixed meals determined by the ELISA and HPLC methods and attempt to evaluate their usability for monitoring studies. Polish Journal of Food and Nutrition Science, Olsztyn, v.8, n.1, p.53-64, 1999.

JECFA. Expert Committee on Food Additives. Geneva: Joint FAO/WHO, 1995. (Technical Report Series, n.859)

JIAO, Y. Identification of ochratoxin A in food samples by chemical derivatization and gas chromatography mass spectrometry. Journal Chromatography A, Amsterdam, v. 95, n.1/2, p.364-367, 1992.

JORNET, D.; BUSTO, O.; GUASH, J. Solid phase extration applied to the determination of ochratoxin A in wines by reversed-phase high-performance liquid chromatography. Journal of Chromatography A, Amsterdam, v.882, p.1-2, p.29-35, 2000.

JORSENSEN, K. Survey of pork, poutry, coffee, beer and pulses for ochratoxin A. Food Additives and Contaminants, London, v.15, n.5, p.550-554, 1998.

KAWAMURA, O. et al. A sensitive Enzyme-Linked Immunosorbent assay of Ochratoxin A based on 
Monoclonal Antibodies. Toxicon, Elmsford, v.27, n.8, p.887-897, 1989.

KAWAMURA, O. et al . Enzyme-Linked Immunosorbent assay for detection and survey of Ochratoxin A in livestock sera and mixed feeds. Food and Agricultural Immunology, Norvich, v.2, p.135-143, 1990.

KWAK, B. Y.; SHON, D. H. Detection of ochratoxin A in agricultural commodities using enzyme linked immunosorbent assay. Food Science and Biotechnology, v.9, n.3, p.168-173, 2000.

LARSEN, T. O.; SVENDSEN, A.; SMEDSGAARD, J. Biochemical characterization of ochratoxin A producing strains of the genus Penicillium. Applied Environmental Microbiology, Washington, v.67, n.8, p.3630-3635, 2001.

LEE, S. C.; CHU, S. C. Enzyme linked immunosorbent assay of ochratoxin A in wheat. Journal of the Association of Official Analytical Chemists, Arlington, v.67, n.1, p.4549, 1984.

LEE, H. B.; MAGAN, N. Environmental factors and nutritional utilization patterns affect niche overlap indices between Aspergillus ochraceus and other spoilage fungi. Letters in Applied Microbiology, Oxford, v.28, p.300-304, 1999.

LEONI, L. A. B.; VALENTE SOARES, L. M.; OLIVEIRA, P. L. C. Ochratoxin A in Brazilian roasted and instant coffees. Food Additives and Contaminant, London, v.17, n.10, p.867-870, 2000.

LEONI, L. A. B. et al. Ochratoxin A in Brazilian green coffees. Ciência e Tecnologia de Alimentos, Campinas, v.21, n.1, jan. 2001.

LEVI, C. P.; TRENK, H. L.; MOHR, H. K. Study of the Occurence of Ochratoxin A in Green Coffee Beans. Journal of the Association of Official Analytical Chemists, Arlington, v.57, n.4, p.866-870, 1974.

LEVI, C. P. Mycotoxins in Coffee. Journal of the Association of Official Analytical Chemists, Arlington, v.63, n.6, p.1282-1285, 1980.

LLORENS, A. et al. Comparation of extration and clean up procedures for analysis of zearalenone in corn, rice and wheat grains by high-performance liquid chromatography with photodiode array and fluorescence detection. Food Additives and Contaminants, London, v.19, n.3, p.272-281, 2002.

MARTINS, D. O. Use of a commercial enzyme-linked immunosorbent assay (Elisa) for detection and quantification of ochratoxin $\mathrm{A}$ in green coffee. In: INTERNATIONAL IUPAC SYMPOSIUM ON MYCOTOXINS AND PHYCOTOXINS, 10,, 2000, Guaujá. Resumos... Guarujá, 2000. p.19.
MATEO, J. J. et al. Critical study of and improvements in chromatographic methods for the analysis of type B trichothecenes. Journal of Chromatography A, Amsterdam, v.918, n.1, p.99-112, 2001.

MAZZAFERA, P.; YANO, D. M. Y.; VITÓRIA, A. P. Pra que serve a cafeína em plantas? Revista Brasileira de Fisiologia Vegetal, v.8, n.1, p. 67-74, 1996.

MISLIVEC, P. B. Incidence of toxigenic and other molds in green coffee beans. Journal of Food Protection, Des Moines, v.46, n.11, p.969-973, 1983.

MOSS, M.O. Mode of formation of ochratoxin A. Food Additives and Contaminants, London, v.13, p.5-9, 1996. Suplemento

MUNKVOLD, G. P.; HELLMICH, R. L.; RICE, L.G. Comparation of fumonisin concentrations in kernels of transgenic Bt maize hybrids and no transgenic hybrids. Plant Disease, St. Paul, v.83, n.2, p.130-132,1999.

NAIK, J. P.; NAGALAKSHMI, S. Determination of caffeine in tea products by an improved igh-performance liquid chromatography method. Journal of Agricultural and Food Chemistry, Easton, v.45, p.3973-3975, 1997.

NAKAJIMA, M. et al. Determination of Ochratoxin A in Coffee Beans and Coffee Products by Monoclonal Antibody Affinity Chromatography. Food and Agricultural Immunology, Novich, v.2, p.189-195, 1990.

NAKAJIMA, M. Mycotoxin Analysis using Immuno affinity Columns. In: INTERNATIONAL SYMPOSIUM OF MYCOTOXILOGY'99, MYCOTOXIN IN CONTAMINATION: HEALTH RISK AND PREVENTION, 1999, Chiba, Japan. Proceeding ... Chiba, 1999. p.172-179.

NEWSOME, W. H. Potential and advantages of immunochemical methods for analysis of foods. Review: Immunochemical Methods. Journal of the Association of Official Analytical Chemists, Arlington, v.69, n.6, p.919-923, 1986.

NORTHOLT, M. D.; BULLERMAN, L. B. Prevention of Mold Growth and Toxin Production through Control of Environmental Conditions. Journal of Food Protection, Des Moines, v.45, p.519-526, apr., 1982.

ONO, E. Y. S. et al. Comparative study of indirect competitive ELISA and HPLC for fumonisin detection in corn of the State of Paraná, Brazil. Food and Agricultural Immunology, Novich, v.12, n.1, p.5-14, 2000.

OSTROVE, S. Affinity chromatography: general methods. Methods in Enzymology, New York, v.182, p.357-371, 1990 .

OTTENEDER, H.; MAJERUS, P. Ochratoxin A (OTA) in coffee: nation wide evaluation of data collected by 
German Food Control 1995-1999. Food Additives and Contaminants, London, v.18, n.5, p.431-435, 2001.

PASTER, N.; PUSHINSKY, A.; MENASHEROV, M. Inhibitory Effect of Aspergillus niger on the Growth of Aspergillus flavus, and on Aflatoxin Formation. Journal of Science Food Agricultural, London, v.58, p.589-591, 1992.

PESTKA, J. J. et al. Comparative assessment of fumonisin in grain based foods by ELISA, GC-MS, and HPLC. Journal of Food Protection, Des Moines, v.57, n.2, p.169-172, 1994.

PESTKA, J. J.; ABOUZIED, M. N.; SUTIKNO. Immunological assays for mycotoxin detection. Food Technology, Chicago, v.49, n.2, p.102-107,1995.

PETRACCO, M. Melhoramento da Qualidade do Café pela Redução do Crescimento de Fungos. In: ENCONTRO NACIONAL DE MICOTOXINAS. 9., 1998, Florianópolis. Anais...Florianópolis, 1998.

PETTIGREW, J. Café. São Paulo: Nobel, 1999.

PFOHL LESZKOWICZ, A. et al. Balkan endemic nephropathy and associated urinary tract tumours: a review on aetiological causes and the potential role of mycotoxins. Food Additives and Contaminants, London, v.19, n.3, p.282-302, 2002.

PIMENTA, C. J.; COSTA, L.; CHAGAS, S. J. R. Peso, acidez, sólidos solúveis, açúcares e compostos fenólicos em café (Coffea arabica L.) colhidos em diferentes estádios de maturação. Revista Brasileira de Armazenamento, Especial Café, Viçosa, n.1, p.23-30, 2000.

PITTET, A. et al. Liquid chromatographic determination of ochratoxin A in pure and adulterated soluble coffee using na immunoaffinity column cleanup procedure. Journal of Agricultural and Food Chemistry, Easton, v.44, p.3564-3569, 1996.

PITTET, A.; ROYER, D. Rapid, low cost thin layer chromatographic screening method for the detection of ochratoxin A in green coffee at control level of $10 \mathrm{mg} / \mathrm{kg}$. Journal of Agricultural and Food Chemistry. Easton, v.50, n.2, p.243-247, 2002.

PLESTINA, R. Nephrotoxicity of ochratoxin A. Food Additives and Contaminants, London, 13, p. 49-50, 1996. Supplement.

PRADO, G. et al. Incidência de ocratoxina A em café torrado e moído e em café solúvel consumido na cidade de Belo Horizonte, MG. Ciência e Tecnologia de Alimentos, Campinas, v.20, n.2, p.192-196, ago. 2000,

PRUSKY, D. New alternatives for the control of postharvest disease affecting tropical fruits. In: SINCOBIOL. 5., 1996, Foz do Iguaçu. Anais: Conferência e palestras... Foz do Iguaçu, 1996. p.49-56.
RITCHIE, F.R. Preparation of polyclonal antisera. Section A. General Methodology. In: ROSE, Noel R. Rose. $M a-$ nual of clinical laboratory immunolog. 3.ed. Washington: American Society for Microbiology. 1986. Chapter 2, p.4-9.

ROMANO-MACHADO, J. et al. Caffeine degradation in fresh and ensiled coffee pulp by solid state fermentation: influence of substrate pretreatment and inoculum level. In: SEMINÁRIO INTERCIONAL SOBRE BIOTECNOLOGIA NA AGROINDUSTRIA CAFEEIRA. 3., 1999, Londrina. Anais... Londrina, 1999. p.365-372.

ROUSSOS, S. et al. Caffeine degradation by Penicillium verrucosum in solid-state fermentation of coffee pulpcritical effect of additional inorganic and organic nitrogen sources. Journal of Food Science and Technology, Oxford, v.31, n.4, p.316-319, 1994

ROUSSOS, S. et al. Biotechnological management of coffee pulp-isolation, screening, characterization, selection of caffeine-degrading fungi and natural microflora present in coffee pulp and husk. Applied Microbiology and Biotechnology, Berlim, v.42, p.756762, 1995.

SAMARAJEEWA, U. et al. Application of immunoassays in the food industry. CRC Critical Rewiews in Food Science and Nutrition, Cleveland, v.29, n.6, p.403-434, 1991.

SCHWARTZ, G. G. Hypothesis: does ochratoxin A cause testicular cancer? Cancer Causes \& Control, Frankfurt, v.13, n.1, p.91-100, 2002.

SCOTT, P. M.; TRUCKSESS, M. W. Application of Immunoaffinity Columns to Mycotoxin Analysis. Journal of the Association of Official Analytical Chemists, Arlington, v.80, n.5, p.941-949, 1997.

SCUSSEL, V. M. Micotoxinas em alimentos. Florianópolis: Insular, 1998.

SIBANDA, L. et al. Development of a Flow through enzyme immunoassay and application in screening green coffee samples foe ochratoxin A with confirmation by High Performance Liquid Chromatography. Journal of the Food Protection, Des Moines, v.64, n.10, p.15971602, 2001.

SOARES, L..M.V.; RODRIGUEZ AMAYA, D. B. Screening and quantitation of ochratoxin A in corn, peanuts, beans, rice and cassava. Journal of the Association of Official Analytical Chemists, Arlington, v.68, p.1128-1130, 1985.

SOLEAS, G. J.; YAN, J.; GOLDBERG, D. M. Assay of ochratoxin $\mathrm{A}$ in wine and beer by high pressure liquid chromatography photodiode array and gas chromatography mass selective detection. Journal of 
Agricultural and Food Chemistry, Easton, v.49, n.6, p.2733-2740, 2001.

SOLFRIZZO, M.; AVANTAGGIATO, G.; VISCONTI, A. Use of various clean-up procedures for the analyses of ochratoxin A in cereals. Journal of Chromatography $A$, Amsterdam, v.815, p.67-73, 1998.

SOUZA, S. M .C.; CARVALHO, V. L. Efeitos de microrganismos na qualidade da bebida do café. Informe Agropecuário, Belo Horizonte, v.18, n.187, p.21-23, 1997.

SPOTS, R. A.; CERVANTES, L. A. Populations, pathogenicity, and benomyl resistance of Botrytis spp., and Mucor piriformis in packing houses. Plant Disease, St Paul, v.70, p.106-108, 1986.

STOEV, S. D. The role of ochratoxin A as a possible cause of Balkan endemic nephropathy and its risk evaluation. Veterinary and Human Toxicoogyl, Manhatan, v.40, n.6, p.352-360, 1998.

STOEV, S. D. et al. Spontaneous mycotoxins nephropathy in Bulgarian chickens with unclarifield mycotoxin aetiology. Veterinary Research, Le Ules, v. 33, n.1, p. 83-93, 2002.

STUDER-ROHR et al. The occurence of Ochratoxin A in Coffee. Food and Chemical Toxicology, Kidlington, v.33, n.5, p.341-355, 1995.

SWEENEY, M. J.; WHITE, S; DOBSON, A. D. W. Mycotoxins in agriculture and food safety. Irish Journal of Agricultural and Food Research, Dublin, v.39, p.235244,2000

TAIZ, L.; ZEIGER, E. Plants Defenses: Surface Protectants and Secondary Metabolites. In: Plant Physiology. Sunderland: Sinauer Associates, 1998. Cap. 13, p.347-375.

TANIWAKI, M. H.; BANHE, A. A.; IAMANAKA, B. T. Incidência de fungos em café. In: ENCONTRO NACIONAL DE MICOTOXINAS, 1., SIMPOSIO EM ARMAZENAGEMQUALITATIVA DE GRÃOS DO MERCOSUL, 9., 1998, Florianópolis. Resumos... Florianópolis, 1998.

TANIWAKI, M. H.; BANHE, A. A.; IAMANAKA, B. T. Incidência de fungos em café. In: SEMINÁRIO INTERNACIONAL SOBRE BIOTECNOLOGIA NA AGROINDUSTRIA CAFEEIRA. 3., 1999, Londrina. Anais... Londrina, 1999. p.487-492.

TANIWAKI, M. H.; PITT, J. I.; TEIXEIRA, A. A. Fungi producing ochratoxin A in coffee. In: INTERNATIONAL IUPAC SYMPOSIUM ON MYCOTOXINS AND PHYCOTOXINS. 10., 2000, Guarujá. Resumos... Guarujá, 2000. p.180.
TAVARES, S. C. C. H. Controle biológico clássico de patógenos de frutos no Brasil-Situação atual. In: SINCOBIOL. 5., 1996, Foz do Iguaçu. Anais: Conferências e palestras... Foz do Iguaçú, 1996. p.57-68.

TERADA, H. et al. Liquid Chromatographic determination of Ochratoxin A in coffee beans and coffee products. Journal of the Association of Official Analytical Chemists, Arlington, v.69, n.6, p.960-964, 1986.

TOLEDO, L. Os diferentes sabores e preços do café brasileiro. Revista Exportar \& Gerência,Brasília, n.20, p.1824, maio 2000.

TRUCKSESS, M.W. et al. Determination and Survey of Ochratoxin A in Wheat, Barley and Coffee. Journal of the Association of Official Analytical Chemists, Arlington, v.82, n.1, p.85-89, 1999.

TRUCKSESS, M. W. Rapid analysis (Thin layer chromatographic and immunochemical methods)for mycotoxins in food and feeds. In: INTERNATIONAL IUPAC SYMPOSIUM ON MYCOTOXINS AND PHYCOTOXINS. 10., 2000, Guarujá, Resumos... Guarujá, 2000. p.5.

TSUBOUCHI, $\mathrm{H}$. et al. Caffeine degradation and increased ochratoxin A production by toxigenic strain of Aspergillus ochraceus isolated from green coffee beans. Mycopathologia, Dordrecht, v.90, p.181-186, 1985.

TUYL, J.V. Genetic of fungal resistance to systemic fungicides. Mededelingen Landbouwhogeschool Wageningen, Wageningen, v.77, n.2, p.1-45, 1997.

UENO, Y. et al. A 4 year study of plasma ochratoxin A in a selected population in Tokyo by immunoassay and immunoaffinity column linked HPLC. Food and Chemical Toxicology, Kidlington, v.36, p.445-449, 1998.

URBANO, G. R. et al. Incidence of toxigenic fungi and ochratoxin A detection in coffee from three brazilian regions. In: INTERNATIONAL IUPAC SYMPOSIUM ON MYCOTOXINS AND PHYCOTOXINS. 10., 2000, Guarujá, Resumos... Guarujá, 2000. p.164.

URBANO, G. R. et. Occurrence of ochratoxin A producing fungi in raw Brazilian coffee. Journal Food Protection, Des Moines, v.64, n.8, p.1226-1230, 2001.

VAN EGMOND, H. P. Methods for determining ochratoxin A and others nephrotoxic mycotoxins. IARC Sci. Publ, v.115, p.57-70, 1991.

VAN EGMOND, H. P. Analytical Methodology and regulations for ochratoxin A. Food Additives and Contaminants, London, v.13, p.11-13, 1996. Supplement

VOLLER, A.; BIDWELL, D. Enzyme-linked immunosorbent assay. Section B. Immunoassay. In: ROSE, Noel R. Rose. Manual of clinical laboratory 
immunolog. 3.ed. Washington: American Society for Microbiology. 1986. p.99-110.

$\mathrm{XIAO}, \mathrm{H}$. et al. Improved methods for conjugating selected mycotoxins to carrier proteins and dextran for immunoassays. Journal of Agricultural and Food Chemistry, Easton, v.43, p.2092-2097, 1995.

XIAO, H. Synthesis and structural elucidation of analogs of ochratoxin A. Journal of Agricultural and Food Chemistry, Easton, v.43, p.524-530, 1995.
XIAO, H.et al. Toxicity of ochratoxin A, its opened lactone form and several of its analogs: estructure-activity relationships. Toxicology and Applied Pharmacology, Orlando, v.137, n.2, p.182-192, 1996.

WILLET, M. J. et al. Integrated management of postharvest diseases and disorders of apples, pears, and cherries. Postharvest Pomology Newsletter, Washington, v.7, n.3, p.3-16, 1992. 
